\title{
ASPECTS OF THE ANCIENT GREEK SYMPOSION
}

\author{
WJ Henderson (Rand Afrikaans University)
}

\section{Introduction}

For the duration of its history in the period when Greece was still a predominantly oral culture, deep into the 4th century BC, the symposion was one of the most important places where citizens, young and old, were prepared for their civic roles in the city-state. At the same time it provided the context in which poetry, as one of the media in the educational process, was created, communicated and preserved. Its religious-philosophical character and its secure and frank environment provided a context conducive to intellectual debate, friendly and genial association, and the uninhibited enjoyment of sensual pleasures.

Although some scholarly attention was focused on the symposion in the late 19th and early 20th centuries, for example in the work of Reitzenstein (1893), Von der Mühll (1983), ${ }^{1}$ Martin (1931) and Hug (1960a, b), it is really only in the past two decades that research on the symposion in Greece and its equivalents in other parts of the ancient world has burgeoned. ${ }^{2}$ The papers presented at three recent symposia on the symposion, the first in Oxford in 1984, the second at McMaster University, Ontario, Canada, in 1989, and the third at the British School in Rome in 1991 (cf. Murray 1990a; Slater 1991a; Murray \& Tecuşan 1995), as well as "non-sympotic" papers, have dealt with a wide range of aspects of the symposion, from its physical space and accessories to its social and intellectual role, and demonstrate the profound significance of this institution as something far more than only an occasion to "drink together" (Latacz 1990:227-228).

The primary sources that are connected directly and contemporaneously to the symposion are (1) the poetry performed during symposia, (2) the painted pottery made for and used during the occasion, and (3) the archaeological remains of diningrooms, all of which are in a severely fragmented state. The sympotic poetry describes the physical milieu (people, objects, activities) and expresses the expectations and ideals, and the emotional and intellectual content of these gatherings; the vasepaintings present visual depictions of sympotic scenes going back to the 8th century, at the beginning of the development of the Greek city-states; and archaeology recreates the physical space. The information found in these sources can be corroborated and expanded from prose writings and later poetry. Here Athenaeus' Deipnosophistai is our richest source. However, although these sources furnish many realistic details of use to us, they conjure up an entirely unreal symposion, in fact a literary construct, of the real-life symposion. The classical model for a gathering where men, after a simple meal, pass the time in intellectual debate, is Plato's Symposion. However, what he creates (or recreates) is an ideal symposion, while in

1 The original lecture, entitled "Das griechische Symposion", was delivered in 1926, first appeared in 1957 and was reprinted in 1976.

2 Cf. the works listed by Latacz 1990:259-264 and Bowie 1997:1. 
his other works he holds both negative and positive views of the "real" symposion (Tecuşan 1990; Slater 1991b:2-3). The same applies to Xenophon's Symposion. Philoxenus of Leucas, a lyric poet of (probably) the late 4th century, wrote an entire poem on the banquet ( $\delta \varepsilon i ́ \pi v o v$ ). Its surviving pieces (Fr. 836a-d $P M G$ ) provide a repertoire of the procedures and kinds (though not the quantity!) of food and drink at symposia. The fragments have more antiquarian than literary value, liberally sprinkled as they are with extravagant language, neologisms, daring compounds and linguistic rarities to suit the fare.

The main aim of this article is to provide a survey of the development, function, activities and nature of the symposion. This entails a synthesis of much of the material from recent publications, though I have also expanded or added ideas where I considered it warranted. A secondary aim is to include the direct evidence of sympotic lyric (= melic) poetry. ${ }^{3}$ And, because the surviving lyric poetry originally sung at symposia is so fragmentary, a coherent, meaningful discussion of these texts can only be undertaken in the broader context reconstructed from the other available sources.

\section{The origin and development of the symposion}

Communal meals must have appeared very early in Greek cultural history, probably as informal gatherings of friends with some shared bond (war, politics, hunting), where food and wine, conversation and singing were essential elements. However, the extant literary evidence dates only from the mid-8th century. Murray (1983a; 1991:92-94; 1995:8) locates the origin of the symposion (and Spartan syssition) in the privileges of the military class, and specifically in the merit feasts of the Homeric

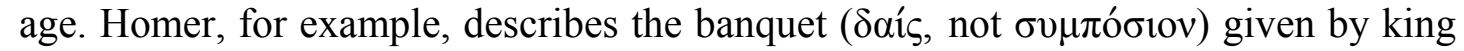
Alcinous of the Phaeacians in honour of Odysseus (Od. 8.38-420). All the leading citizens are invited $(39,40-41,43)$. There are perhaps a hundred guests: fifty-two young men are ordered to prepare the ships (48), there were "many, young and old" (58), and twelve sheep, eight wild boars and two oxen are slaughtered (59-60). The blind poet-singer Demodocus is also summoned and given a place at the table (43-45, 62-70), and, after all have enjoyed the food and wine, he treats the guests with songs of heroic deeds, while he accompanies himself on a lyre (71-103). Then the guests move outdoors where they participate in various sports (boxing, wrestling, jumping and running, 104-249), while "many thousands" ( $\mu v \rho i ́ o r, 110)$ stand and watch. This is followed by dancing, more eating and drinking, more singing, and the presentation of gifts to Odysseus, who then takes a bath before the evening banquet, during which he delivers his long narration $(250-586)$. The occasion lasts an entire day $(8.1 ; 13.17-$ 18).

It is clear that we are dealing here with an epic, heroic banquet on a large scale. One can see this in the relation between the narrative time and the narrated time: although the narrative and narratives-within-the-narrative take up five books, the actual occasion only occupies one day (anticipating James Joyce's Ulysses!). Homer is recreating the atmosphere of a royal banquet in a by-gone age of heroes;

3 On sympotic elegiac poetry, cf. Henderson 1997. 
what is described here is strictly speaking not a symposion (Von der Mühll 1983:5-6; Slater 1990:213-217). The usual symposion did not have the enormous number of guests, the sporting-activities outside the banquet-hall, or the thousands of spectators, and it did not last quite as long. Still, there are common elements: aristocratic guests, genial company, specific codes of behaviour, the moderate consumption of food and wine, a poet who entertains the guests with song and lyre-accompaniment, the exchange of gifts, and games. The Homeric sais is the predecessor of the true symposion in the sense that it offered the space and occasion for physical and intellectual pleasure, and, in particular, for the performance and reception, in short the communication, of poetry (Latacz 1990:229-231; Rösler 1990:230).

The occasion also serves to reinforce bonds of friendship and a sense of identity among the guests. Odysseus is welcomed as an unknown stranger, and it is in his honour that the banquet is held. Demodocus sings of Greek heroes at Troy, including Odysseus, who, during this performance, keeps his identity and grief hidden (Od. 8.72-95). The song ironically connects Odysseus with the non-Achaean audience. The athletic items that follow are characterized by intense competitiveness which engenders pride and unites the Phaeacians to the point where they challenge the stranger (110-151). When Odysseus declines the challenge, it is felt as an insult (159-164). When Odysseus reacts in anger and triumphs, he is immediately accepted (165-255). The presentation of gifts to Odysseus by the twelve kings is intended to appease him, but also results in friendship and the exchange of good wishes (390415). During the evening banquet, Demodocus, at the request of the stranger, again sings of the Trojan heroes, especially Odysseus (470-520). When Alcinous sees Odysseus weeping, he stops the singer, and explains (542-547):

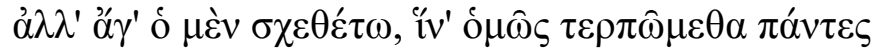

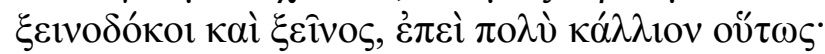

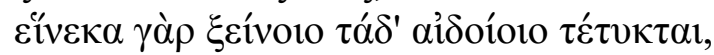

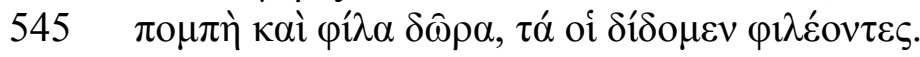

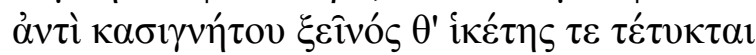

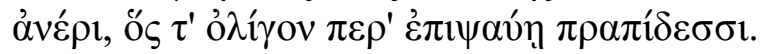

But come, let him stop, so that we can all enjoy ourselves together, we the hosts and our guest, for it is much better thus.

In fact, these arrangements have been made for our honoured guest, the occasion and our own gifts, which we present to him as friends.

A stranger and a suppliant are like a brother

to any man who has a touch of common-sense, even a little. ${ }^{4}$

In the rest of his speech, with which the book closes, Alcinous firmly requests Odysseus to reveal his identity (548-586).

When Odysseus replies, at the beginning of the next book (Od. 9.3-11), he gives what is, according to Burkert (1991:19), perhaps the earliest description of a symposion:

4 The translations are by the author, unless stated otherwise. 


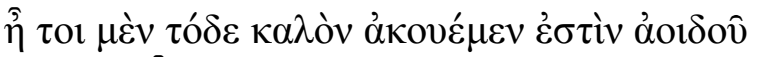

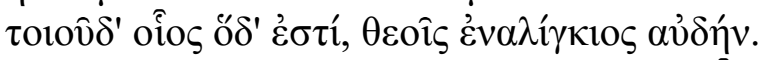

5

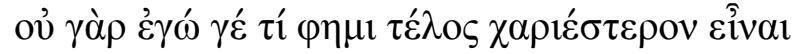

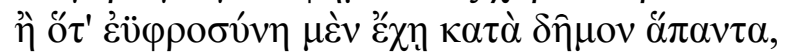

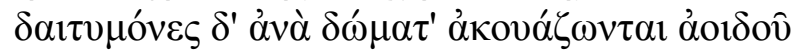

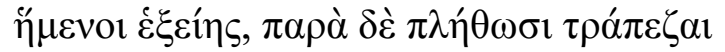

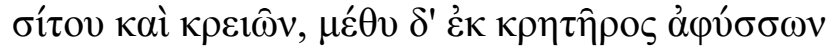

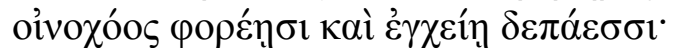

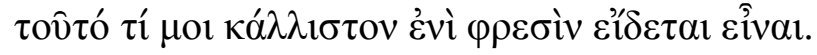

This is indeed beautiful, to listen to a singer such as he is, his voice resembling that of gods. For my part, I say there's no pleasanter highlight than when merriment takes hold of all the people, and they dine in halls and listen to a singer, sitting in order, and the tables alongside are filled with bread and meat, and the wine-pourer draws wine from the mixing-bowl, brings and pours it in the goblets: this seems to me in my heart to be the fairest thing.

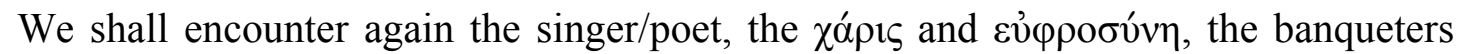
arranged in a specific order, the tables of food and wine, the wine-pourers, the $\kappa \rho \alpha \tau \hat{\jmath} \varepsilon \varsigma \varsigma$ and drinking-cups. But there will also be changes: the banqueters will be reclining, not sitting; the wine will be more explicitly mixed with water (here $\mu \dot{\varepsilon} \theta v$ may refer to a pure, sweet, meady wine, despite the presence of the krater); and other

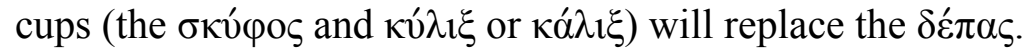

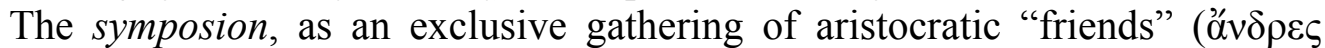

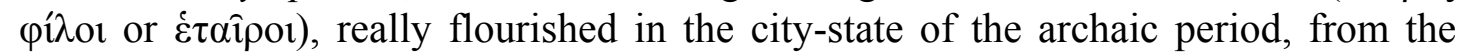
early 7th to the late 5th century, precisely the period of transition from a predominantly oral to a literate culture (Latacz 1990:228). Although it continued as an institution in the Graeco-Roman world into the 6th century AD (Murray 1983b; West 1990; Rathje 1990; D'Arms 1990), by the late 5th century BC the exclusive, mostly aristocratic groups of the symposia, with their frequent bad behaviour and excesses, especially during the $\kappa \omega \hat{\omega} \mu \varsigma$, were no longer a significant factor for the democratic Athenians in their political, social and cultural life. Solon had already in his day attacked this behaviour (Fr. 4.7-10 West): ${ }^{5}$

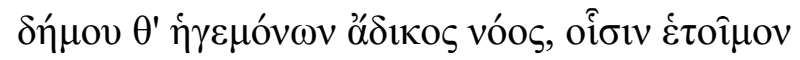

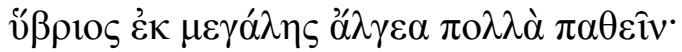

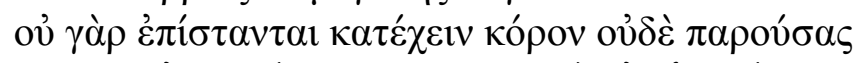

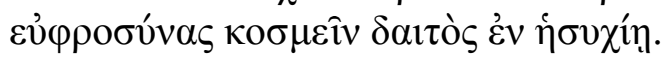

But the mind-set of the leaders of the people is unjust. For them waits, because of their great pride, suffering of much grief,

$5 \quad$ West 1992. 
for they don't know how to check their excessive wealth or how to control the pleasure of their present feast in peace.

The sense of $\dot{\sigma} \sigma u \chi i$ here is "restraint", and the plea is for moderation of enjoyment (Dickie 1984:84). Though the symposion per se was not anti-democratic (Bowie 1997:3), the development of democracy in Athens left little room for the traditional, elitist, aristocratic symposion (Murray 1990c:150; Rösler 1990:236).

\section{The agenda of the symposion}

Participants at a modern symposium may or may not know of its origin as "a drinking together" ( $\sigma v v-/ \sigma v \mu-$ plus $\pi$ ó $\sigma \varsigma)$, but do expect a gathering of peers, a large amount of talking and a certain intellectual content and level. This expectation is not far from that of the ancient Greek symposiast: there is probably a direct line of development from the ancient Greek symposion, via the Roman convivium and the philosophical schools of Late Antiquity and the Byzantine period, to the learned, academic societies of Western Europe in the Middle Ages, and so to our time (Von der Mühll 1983:1920).

The symposion was actually one phase of a much longer process. First there was the initial $\kappa \hat{\omega} \mu \mathrm{\zeta}$, or procession of guests to the banquet; secondly the $\delta \varepsilon i \bar{\tau} v o v$, the banquet or dinner itself; then came the $\sigma 0 \mu \pi$ ó $\sigma \mathrm{ov}$, during which wine but no food was served; then followed the $\kappa \hat{\omega} \mu \mathrm{s}$, a procession of festive and even rowdy singing and dancing in the streets; and finally came the $\pi \alpha \rho \alpha \kappa \lambda \alpha v \sigma i \theta v \rho o v$, the serenade outside the closed door(s) of female friends or a brothel (Von der Mühll 1983:7-8, 19; Mau 1958; Murray 1990b:6; Lukinovich 1990:263-264; Bowie 1997:2). During and for each phase of this process, large quantities of literary and sub-literary verse have been generated, also in cultures and languages other than Greek (Henderson 1973; Hug 1990b).

At the beginning of the banquet-phase, water was provided for the guests to wash their hands. Then garlands of flowers were placed around their temples and scented oil was served to rub on their hands, faces and hair. Sometimes incense was also burned in the room. Meanwhile the wine and water were mixed in large mixing-

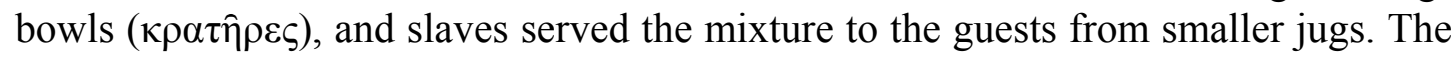
food mostly consisted of various kinds of bread, fish, fowl and meat, cheese, fresh and dried fruit, nuts, honey and various kinds of cake. Music was performed on the lyre or double-pipes. The intention was to stimulate all the senses with colours,

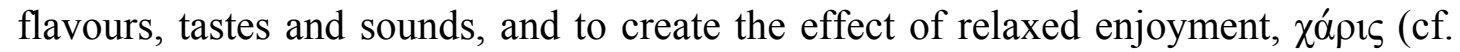
Lissarrague 1990:19, 47; Henderson 1997:6 on Xen. Fr. 1 W; Plut. Quaest. Conv. 621B-E).

In the sympotic phase a variety of activities took place while wine continued to be served. Libations of neat wine were dedicated to Zeus Soter or "the good divinity" ( $\dot{\alpha} \gamma \alpha \theta$ ò $\delta \alpha i ́ \mu \omega v)$ and other Olympian gods, to the heroes, and a prayer offered to Dionysus, or sometimes to Zeus and other gods, followed by the singing of a paean (Diod. Sic. 4.3; Plut. Mor. 655E, 735D-E; Lissarrague 1990:25-26). This constantly emphasized the essentially religious and ritualistic nature of the function. 
The rest of the agenda was taken up in serious and light activities. First, and most important, was the singing of songs/poems to the accompaniment of the lyre or pipes (and sometimes of a female dancer). According to the scholiast on Plato's Gorgias 451E and Aristophanes' Vespae 1222 the singing took on two forms (apart from the earlier paean). In one form all the guests took turns in singing the latest "hits". A myrtle-branch was handed to one guest, who then stood up and began to sing a particular song. He could stop at any point in the song, and hand the branch to someone else, who then had to continue with the song, and again pass the branch on to another guest. Those who could not continue the chosen song, had to withdraw, until eventually only one person remained as the winner.

The other form was to sing an original song/poem, composed shortly before or during the occasion. Only a few guests, mostly poets, took part in this activity. They accompanied themselves on the lyre, or someone else accompanied them on the pipes. It is for this reason that Von der Mühll characterized the symposion as the birth-place of the individual lyric that was not connected with any particular ritual (Von der Mühll 1983:20-21).

A great variety of themes was treated in these sympotic poems: the symposion itself or its elements (especially the mixing, serving, drinking, advantages and dangers of wine, and the need for moderation), the socio-political problems and ills of the city-state, friendship and love (homo- and heterosexual), morality, attitudes towards the gods, the human condition, and carpe diem.

A papyrus (P.Oxy. 2618, fr. 1) preserves a lyric fragment attributed to Stesichorus, who wrote at the turn of the 7 th to 6th century (Fr. $148 S L G){ }^{6}$ The basic elements of the symposion are there: aristocratic banqueters, a poet/singer, wine, festive atmosphere and enjoyment:

[ ] ] ] $\quad$ ]

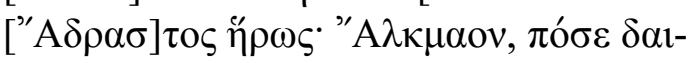

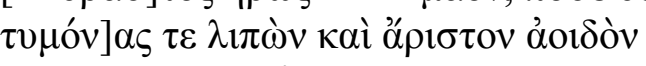

5

[ ] ]

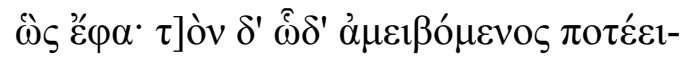

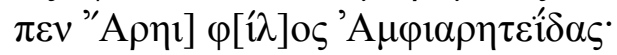

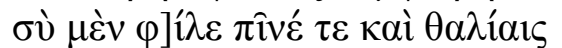

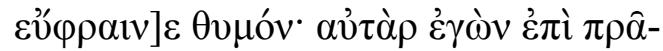

10

$\gamma \mu \alpha]$

...thus he addressed (him...),

the hero Adrastus (?): "Alcmaon, where to, leaving

the guests and the excellent singer,

have you risen (to go...)?"

So he spoke, and the son of Amphiaraus, dear

(to Ares), answered him and said thus:

"You, my friend, drink and with the festivities

$6 \quad$ Page 1974. 
cheer your heart; I, however, on a matter

(...)

A scholiast on Aristophanes, Pax 775 quotes other lines ascribed to Stesichorus (Fr. PMG 210), ${ }^{7}$ which echo some of the items, but in which the main motif is the poet's plea for the exclusion of war as a topic of conversation or song. This is a major departure from the heroic banquet encountered in Homer.

Moî $\alpha$ б

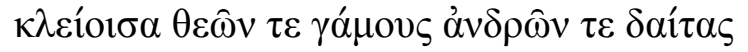

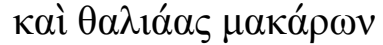

Muse, you must banish wars and with me

praise the weddings of gods and the feasts of men

and the festivities of the blessed.

Some fragments from the sympotic poetry of Bacchylides and Pindar also evoke the atmosphere and content of this part of the symposion.

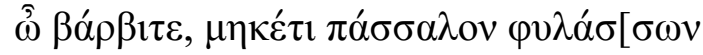

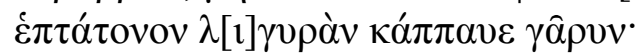

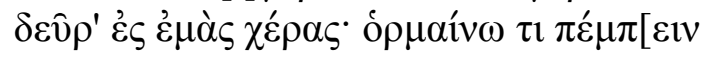

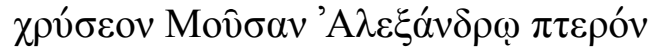

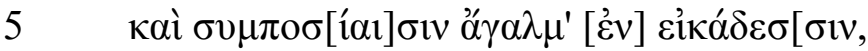

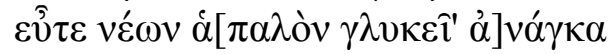

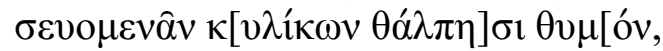

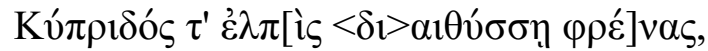

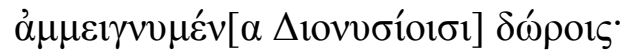

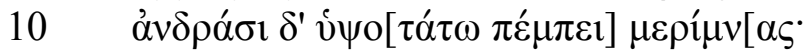

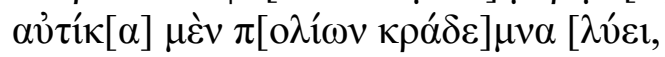

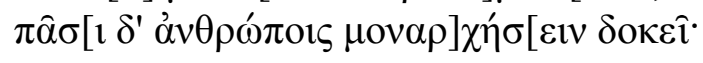

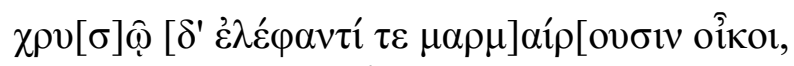

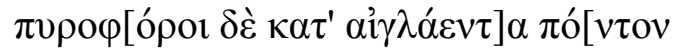

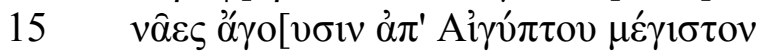

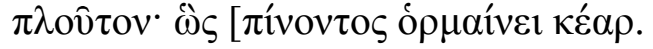

O lyre, guard your peg no more,

nor silence your clear, seven-toned voice.

Come to my hands. I long to send

a golden wing of the Muses to Alexander,

5 some delight for banquets at month's end,

when the (delicious) impetus (of cups) quickly

passed around (warms) young men's (soft) hearts, 
and hope of Aphrodite (rattles their) brains, when mixed with the gifts (of Dionysus).

Wine (sends) men's thoughts soaring: straight away one pulls down (cities' battlements,) while another (thinks he'll rule over all men.)

their houses gleam with gold and ivory, and wheat-bearing ships, over the shining sea, bring great wealth from Egypt.

That's the way (a drinker's heart yearns.)

Bacchylides, Fr. 20B Snell-Maehler ${ }^{8}$

The rest of the fragment is too damaged to yield much more sense, but it seems that the poet goes on to speak of the gratification gained from contemplating good deeds, and of the need to accept both good and bad in life (16-32). The remains, even without the restored gaps, create a vivid picture of a symposion: the lyre-accompanied song, the company, the youthful exuberance, the desires for and hopes of love, power and riches, all stimulated by the consumption of wine. symposion: ${ }^{9}$

Bacchylides also draws a picture of a much simpler and more frugal

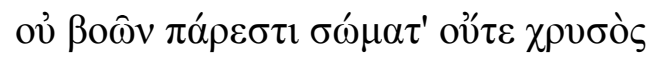

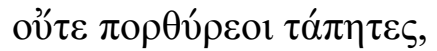

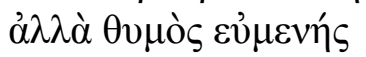

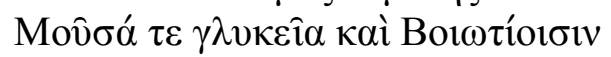

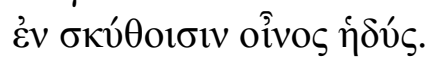

$$
\begin{aligned}
& \text { No ox-carcasses are here, nor gold, } \\
& \text { nor purple carpets, } \\
& \text { but a friendly heart } \\
& \text { and dear Muse and, in Boeotian } \\
& \text { cups, sweet wine. }
\end{aligned}
$$

Fr. 21 Snell-Maehler

The essentials of his type of symposion are companionship, poetry, and wine in Boeotian cups. The latter reference must be to a less artistic, rustic earthenware, associated particularly with the Boeotians. It is notable, however, that Bacchylides views this rusticity and simplicity positively, in contrast with Pindar, Ol. 6.90 and Fr. 83 Snell-Maehler.

Athenaeus $(11.480 \mathrm{C} ; 11.782 \mathrm{D})$ quotes lines from Pindar which probably came from the same poem which the poet explicitly intended to be sung at a symposion.

Snell-Maehler 1970.

Alcman also refers to simpler fare (Frr. 17, 19, 94, 96), garlands (Frr. 60 and 91), wine (Fr. 92) and the singing of paeans (Fr. 98), but in the context of communal meals or informal gatherings

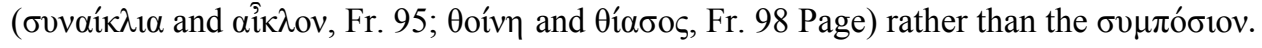


The lines echo Bacchylides' Fr. 20B in celebrating the pleasant company and wine as a remedy for cares and inducer of vain hopes and dreams, but au fond focus on the power of poetry itself:

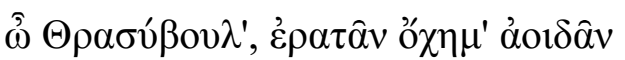

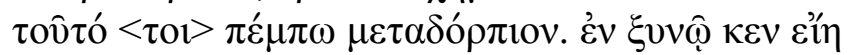

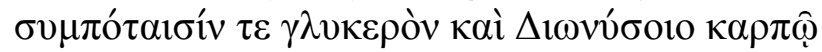

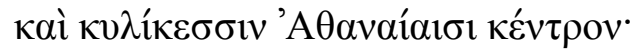

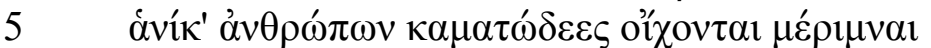

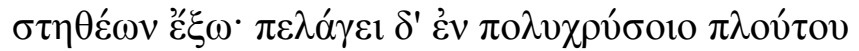

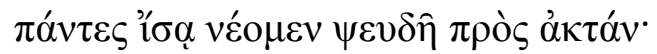

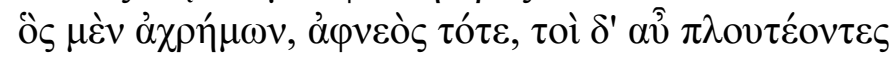

$\cdots$

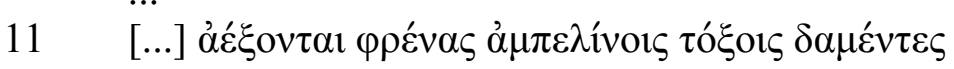

O Thrasybulus, this chariot of lovely songs

I send you for after dinner. In the company

may it be for the banqueters and the fruit of Bacchus

and the Athenian cups a sweet spur,

when men's toilsome cares disappear

from their breasts, and on a sea of gold wealth

we all alike sail towards an imaginary shore;

then he who's poor is rich, while the wealthy ones

...

...

(...) strengthens their minds, tamed by the vine's shafts

Pindar, Fr. 124a, b Snell-Maehler ${ }^{10}$

Pindar uses two related images for his poem: the chariot and the spur. Van Groningen (1960:85-86, 90) rightly rejected LSJ's "raft of songs" (which would relate the trip specifically to a voyage to Sicily, but leave $\kappa \varepsilon ́ v \tau \rho o v$ isolated), and connected the imagery with the two victories of Xenocrates in the quadriga-races. This is possible, but I think it is more important to remember that the chariot (for racing or battle) was the swiftest vehicle known to Pindar and his audience (cf. Henderson 1992:150-151). The presence of $\kappa \dot{v} v \tau \rho o v$ confirms this. The poem is, first, a swift vehicle to transport his thoughts and feelings to his friend in Athens; then it is the stimulus for the symposiasts and the consumption of wine. This last idea is a reversal of the usual view of wine as the stimulus. The reference to Athenian cups not only indicates the recipient's home, but also conveys the idea of luxury (Van Groningen 1960:89-90).

During the symposion (or sometimes after the kômos), кó $\tau \alpha \beta \beta \varsigma$, a very popular game, was played. It was Sicilian in origin, and occurred in a few versions

$10 \quad$ Snell-Maehler 1975. 
(Anacr. Fr. $P M G$ 415; Critias Fr. B2 West; for an illustration, cf. Maas \& Snyder 1989:133 fig. 9). Guests had to throw the last drops in their cups with a quick wristmovement into a bronze bowl some distance away, while, in some versions, naming their beloved. The purpose was to throw accurately, so that there was no mess, and so that a clear, ringing sound was produced as the wine struck the bowl. In a variant form, the guests had to land the wine-drops in saucers floating in water inside the bowl, and make the saucers sink. The game could be quite erotic, as suggested by lines from Bacchylides, where the player is a pipe-player or hetaira:

$\varepsilon v \hat{\tau} \tau$

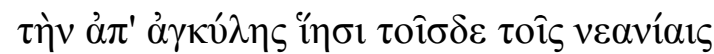

$\lambda \varepsilon v \kappa o ̀ v ~ \alpha ُ v \tau \varepsilon i ́ v \alpha \sigma \alpha \pi \eta \hat{\chi} v v$.

when

from bent wrist she throws for these young men, raising her white forearm.

Fr. 17 Snell-Maehler

Athenaeus (10.427D) states that the libation at the beginning was for the gods, but the kottabos was for the beloved. This, he concludes, explains why ancient drinkingsongs (skolia) are full of references to the game. Then he quotes the following lines from Pindar:

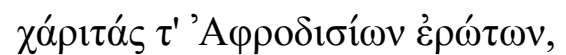

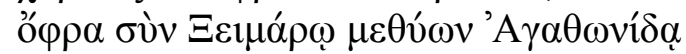

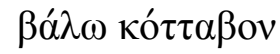

and the charms of Aphrodite's desires,

so that, drunk with Cheimarus, for Agathonidas

I may throw the kottabos

Fr. 128 Snell-Maehler

The lighter, even frivolous, phase of the symposion arrived with the accumulative effect of the wine. Tongues became looser, debates more heated and excited. Guests began to tease one another, especially about their latest love-affairs. They flirted with the dancing-girls and musicians, as well as with the slave-boys who served the wine. In the poems this activity is referred to as "playing" ( $\pi \alpha i \zeta \varepsilon ı v)$. It was this phase that gave wine the reputation of revealing truth, in vino veritas, or, in the words of Alcaeus:

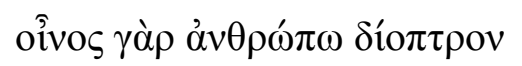


wine is a peep-hole into a man

or

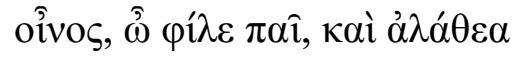

$$
\begin{aligned}
& \text { wine, my dear boy, and the truth }
\end{aligned}
$$

Yet there was a serious side to this process of self-revelation. Plato, in the first two books of the Laws, advocates the role of controlled intoxication to promote the learning process $\left(\pi \alpha 1 \delta \varepsilon_{i} \alpha\right)$, socialization and the revelation of character (Plato, Leg. 642A; Fisher 1989:27-28; Lissarrague 1990:7-11). Plutarch (Mor. 644E-645C) quotes an anecdote about Simonides who said to a particularly silent fellow-symposiast: "If you're a fool, you're acting wisely; if a wise man, foolishly." It was therefore expected that symposiasts share their knowledge, ideas and wisdom with their fellows, that they got to know one another; $\dot{\alpha} \lambda \dot{\alpha} \theta \varepsilon \alpha$ in the above text meant the revelation of all one saw, knew and thought (Rösler 1995:106-107). In Homer (Od. 21.35-36), Odysseus and Iphitus do not manage to get properly acquainted "at table"

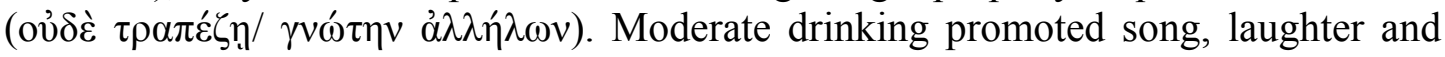
dancing, and intellectual growth; over-indulgence produced only inane chatter and impropriety that profitted no-one.

In the final phase, at the end of a symposion, a group of rather tipsy and rowdy young men, with garlands around their heads or necks and wine-jars in their hands, wandered singing and shouting about the streets in the early hours of the morning in search of female company. This was the closing $\kappa \hat{\omega} \mu$ os, to which we shall return.

\section{The nature of the symposion}

The Greek symposion was, unlike its Roman equivalent, an exclusively male gathering (Mau 1958:610; Murray 1990b:6), where the only women were dancers, musicians, wine-pourers and, from the early 6th century BC, courtesans. ${ }^{12}$ Yet, in spite of the exclusivity of the symposion, its effect spread to the whole community, since the symposiasts were also the political role-players (Schmitt-Pantel 1990:24$25)$. The symposion was therefore one of the most important occasions for aristocrats to learn of and discuss the political, economic and social affairs and developments of their city-state, and to express and affirm (or re-affirm) their common values. In a community not yet served by organized education, it was a centre of education (Murray 1990b:5; Bremmer 1990; Latacz 1990:235-236). ${ }^{13}$ It was also a safe

11 Lobel-Page 1968.

12 Naked women, presumably hetairai, are depicted on Corinthian vases from about 590; cf. Carpenter 1995:152.

13 On education in Greece, cf. especially Harris 1989:15-17, 58-59, 79-80, 96-103; on the role of the poet, cf. Vetta 1983a:XIII, Henderson 1988 and Rösler 1995:109-111. For music as the basis of Greek education, see Plato, Leg. 7.810E. 
environment for the controlled discharge of emotions and the testing of ideas (Plato, Leg. 649D-650B; Pellizer 1990:180-184; Rösler 1995:108-109). Plutarch (Mor.

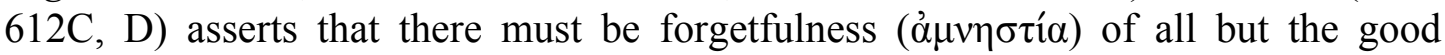
things said and done at a symposion.

The number of persons who attended a symposion was usually 14, 22 or 30, depending on whether there were 7,11 or 15 benches. Athenaeus (3.110F) preserves these lines from Alcman:

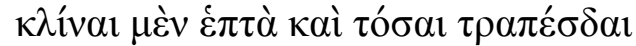

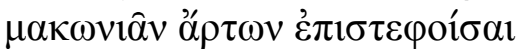

$$
\begin{aligned}
& \lambda^{\prime} \dot{v} \omega \tau \varepsilon \sigma \alpha \sigma \alpha ́ \mu \omega \tau \varepsilon \kappa \eta ่ v \pi \varepsilon \lambda i ́ \chi v \alpha 1 \varsigma \\
& \dagger \pi \varepsilon \delta \varepsilon \sigma \tau \varepsilon \dagger \chi \rho v \sigma о \kappa o ́ \lambda \lambda \lambda \alpha \text {. } \\
& \text { seven couches and just as many tables } \\
& \text { decked with poppy-seed loaves } \\
& \text { and linseed and sesame and chrysocolla } \\
& \text { in [full] bowls. }
\end{aligned}
$$

The size of the room in which the symposion was held varied accordingly from 4,5 metres square to 6,5 metres square (Murray 1990b:7; Bergquist 1990:37). The relatively limited space (about 1,5 sq. metres per person) enhanced the poetic performances and promoted informal discussion, gossip, persuasive argument and, of course, male bonding. In the Minoan and Mycenaean periods everyone sat (thus in Homer), but from about the 7th century, following oriental custom, the symposiasts reclined on high couches (Von der Mühll 1983:6-7; Boardman 1990:122-124). ${ }^{14}$ Young men who attended the symposion with their fathers, and had not yet reached adult status, usually sat (Bremmer 1990:139). They were not allowed to consume wine (Arist. Pol. 1336B20-22). ${ }^{15}$

The symposion had its own codes of conduct, "laws", rituals and activities

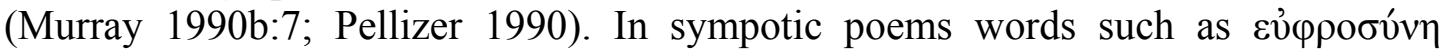

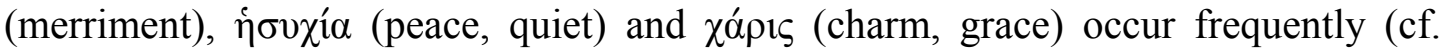
Vetta 1983b:XXXV-XXXIX). We have already referred to Solon's use of $\dot{\eta} \sigma 0 \chi i ́ \alpha$ (Fr. 4.7-10 West); two other key-passages in Pindar are discussed by Dickie (1984:8792):

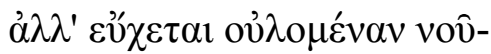

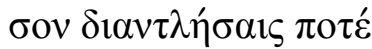

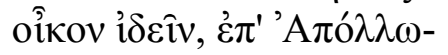

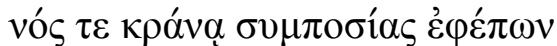

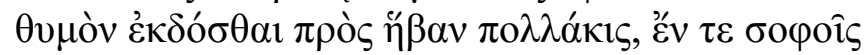

14 The earliest attestation of lying on couches for a feast is Amos 6.4-7 (8th century B.C.); cf. Burkert 1991:10.17-18.

15 Booth (1991:113-117) adduces evidence which suggests that attendance before the age of 18 was unacceptable, but frequently allowed. 


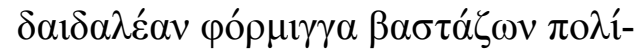

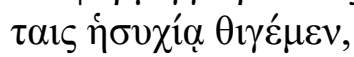

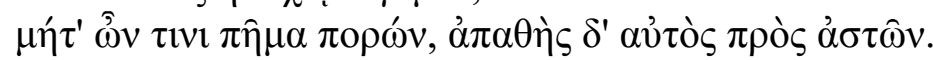

But he prays that, having drained his accursed disease to the end, he may some day see his home; that he may join the symposia at Apollo's fountain, often give his heart over to youthful enjoyment, and, taking up the ornate lyre among his cultured citizens, may attain peace,

neither doing harm to anyone, nor suffering it from his townsmen. ${ }^{16}$

Pindar, Pyth. 4.293-297

$\dot{\eta} \sigma \nu \chi i ́ \alpha \delta \grave{\varepsilon} \varphi \imath \lambda \varepsilon \hat{\imath}$

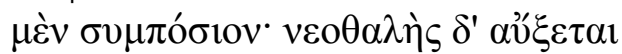

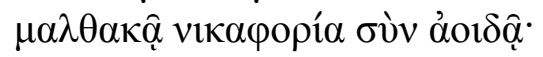

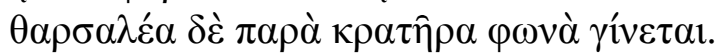

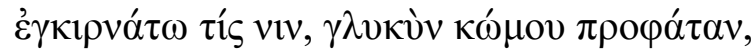

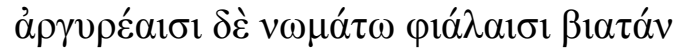
$\dot{\alpha} \mu \pi \dot{\varepsilon} \lambda$ ov $\pi \alpha \hat{\imath} \delta^{\prime} \ldots$

\section{Peace loves} the symposion, but victory increases

with new bloom to the accompaniment of gentle song, and the voice becomes confident beside the winebowl.

Let someone mix that sweet prompter of the revel, and let him serve the powerful child of the vine in the silver bowls... ${ }^{17}$

Nem. 9.48-52

In his Laws, Plato requires of the ideal symposion the necessity of self-control ( $\sigma \omega \varphi \rho о \sigma u ́ v \eta)$, adult symposiasts of 30-60 years old, moderation in the use of wine, someone to monitor and control the activities and behaviour, an educational purpose and effect, orderliness, friendliness and bonhomie-in short, the ideal context for the practice of philosophy (Leg. 639D, F; 641D; 666A ff.; 671B ff.; cf. Bielohlawek 1940:29-30; Tecuşan 1990:241-260). There were, of course, "good" and "bad" symposia, depending on the symposiasts (Plato, Prot. 347C-E), but generally the sources create the impression of a controlled, calm and stimulating atmosphere, rather than one of úpis, violence and insult (Slater 1990:217-218).

One of the central features of the Greek symposion was the moderate use of wine. This motif appears often in elegiac poetry (cf. Henderson 1997:4-20); Fisher

16 Translation by Race 1997:1.297.

17 Translation by Race 1997:2.103-105. 
(1989:30) speaks of "the elegiac tradition of praise of moderate symposia." The Greek symposion, according to this construct, was a controlled, intellectual occasion, where the wine was seldom drunk without water (Hdt. 6.84; Plato, Leg. 637E; Pellizer 1990:178-179; Bérard \& Bron 1989:138; Lissarrague 1990:7-8). The usual proportion was two (or even four) parts of water to one part of wine, and the mixing was supervised by a "master of the symposion" ( $\sigma 0 \mu \pi 0 \sigma i \alpha \rho \chi \circ \varsigma)$. In addition, the symposiasts were expected to drink just enough to make them merry, but still intellectually awake and sharp. ${ }^{18}$

Behind this practice was the belief that wine was a divine gift from Dionysus who alone could drink neat wine without serious consequences (such as madness) (cf. Lissarrague 1990:4-6). He is therefore portrayed on vases with a kantharos (doublehandled drinking-cup) or rhyton (drinking-horn), both of which symbolize undiluted wine (cf. Durand, Frontisi-Ducroux \& Lissarrague 1989:129). Among the remains of Greek lyric poetry there are two fragments which mythologize the dangerous effect of wine on the inexperienced, in this case the Centaurs when they first encountered it. The first fragment is from Pindar:

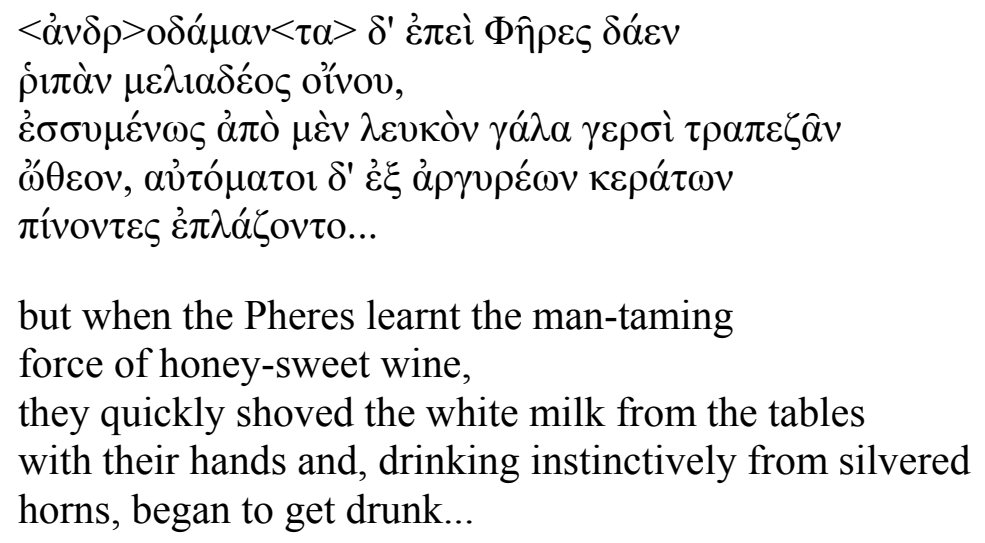

Fr. 166 Snell-Maehler

Several points emerge from the text. Firstly, the power of undiluted wine to subdue

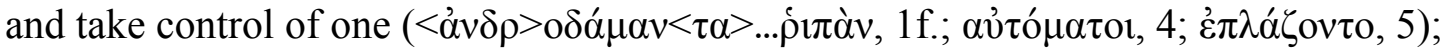
secondly, the beastly, non-human nature of the Centaurs, who, as in Homer, Il. 1.268 and 2.743, are referred to as Pheres (equivalent to $\theta \hat{\eta} \rho \varepsilon \varsigma$, wild animals, non-human

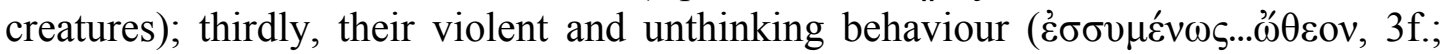

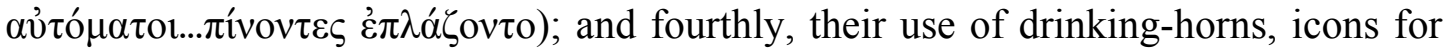
unmixed wine. They feature "as counterexamples to the model of the harmonious

18 Murray (1991:91, $101 \mathrm{nn}$. 22-24) reconstructs the quantity and strength of wine consumed at the Spartan syssitia: $11-12$ choes per month $=52$ litres per person per annum (based on Dicaearchus, fr. 72 Wehrli; Plut. Lyc.12); a minimum of 2 kotylai (0,5 litre) per person per day (based on Hdt. 6.57; Thuc. 4.16). Greek wine was sweet, with 16-17\% alcohol per volume, diluted with two or three parts of water $=5-8 \%$ alcohol (similar to a modern beer). The daily consumption of 0,5 litre, diluted with water, would thus amount to the equivalent of 1-1,5 litres of beer. TzavellaEvjen 1983:187 sets the alcohol content before dilution at around 9-10\%, in her opinion not strong enough to cause the madness claimed in stories. 
banquet" (Lissarrague 1990:28). One is reminded of the scene on the West pediment of the temple of Zeus at Olympia, depicting the uncivilized conduct of the Centaurs, and Apollo's restoration of order, at the marriage of Peirithoos and Hippodameia (cf. Hom. Od. 21.295-304). The scene is also depicted on a red-figure krater (Lissarrague 1990:28, and 30 fig. 14).

The second lyric fragment is by Melanippides:

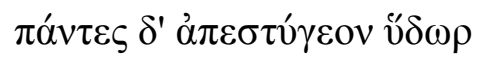

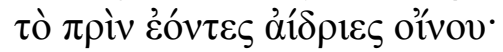

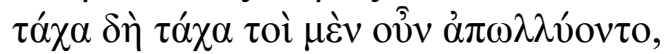

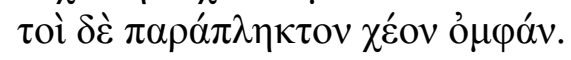

and they all began to hate water,

being until then ignorant of wine;

soon, yes soon, some therefore were dying,

while others were uttering mad cries.

Fr. $P M G 760$

Although neither the fragment, nor Athenaeus who cites it $(10.429 \mathrm{~B}, \mathrm{C})$ offers any clarification, the Centaurs may be the culprits again. What is clear is the effect of undiluted wine (presumably their aversion to water extended to adding it to their wine): death and insanity. Athenaeus himself regarded the belief that wine induced madness as incorrect and an insult to Dionysus, and considered Melanippides ignorant. Of course, there is an element of exaggeration, and if the poet was indeed referring to the Centaurs, the episode is mythological. Athenaeus clearly falls into the category of those who emphasized the positive and therapeutic value of sympotic wine.

There is a fragment by Stesichorus in which the Centaur Pholus acts in a more civilized manner.

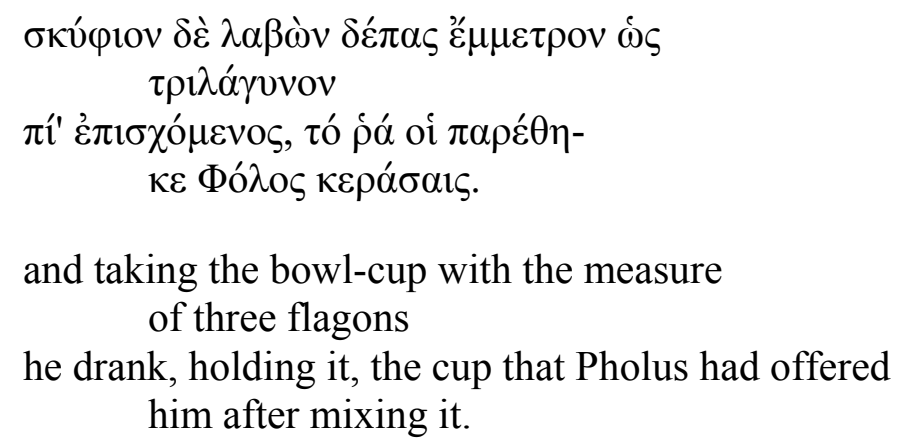

and taking the bowl-cup with the measure of three flagons

he drank, holding it, the cup that Pholus had offered him after mixing it.

Fr. $P M G 181=S L G 19$

Here the Centaur offers Heracles a large cup of diluted wine: both the cup and the diluted wine are typical of civilized, acceptable conduct.

The consumption of wine by mortals had to be controlled by a body of laws, in effect the procedures at symposia. Among these was the mixing of wine with water 


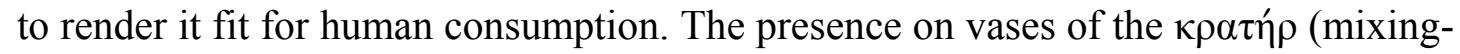
bowl) symbolizes this mixing and the values of moderation (cf. Durand, FrontisiDucroux \& Lissarrague 1989:128; Lissarrague 1990:19-46). Often, satyrs (nonhumans again) are shown drinking from a wine-skin or rhyton to indicate the undisciplined consumption of undiluted wine (Durand, Frontisi-Ducroux \& Lissarrague 1989:127). Their resultant behaviour symbolizes the perversion of the accepted values: on the opposite side of a scene with a krater, one satyr is shown with his behind in the air and his head buried in the depths of a jar of pure wine (Durand, Frontisi-Ducroux \& Lissarrague 1989:128; Lissarrague 1990:91 fig. 75); others are depicted performing intoxicated tours de force: tripping lightly around a drinkingcup, sipping from a cup while doing a handstand, and balancing a kantharos on an erect penis (cf. Durand, Frontisi-Ducroux \& Lissarrague 1989:121-127; cf. Bérard \& Bron 1989:137-138, and fig. 187c; Lissarrague 1990:13-16, 39-40). Misbehaviour is therefore associated with animal-hybrids such as centaurs and satyrs. They represent the animal element in man (Frontisi-Ducroux 1989:156).

The only humans who are portrayed in vase-paintings as misbehaving are those participating in the komos at the end of the symposion (cf. Lissarrague 1990:96

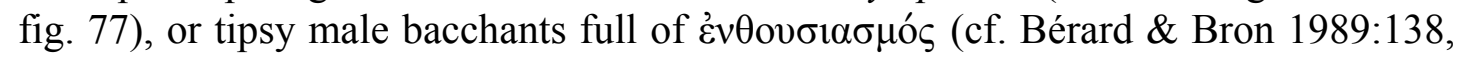
141 fig. 189). The behaviour of the aristocratic komasts, especially, was noisy and destructive and very similar to that of satyrs: they stagger, sit, lie on their backs, drink, fart, ride piggyback (cf. Lissarrague 1990:96 fig. 77). They are, in fact, breaking the sympotic rules of conduct. Their crass and wasteful behaviour was a form of release, but also a proof and manifestation of their solidarity, virility, power and leisure as aristocrats to do what they wished (cf. further Lamer 1965:1288-1290; Adrados 1975:37-40; Durand, Frontisi-Ducroux \& Lissarrague 1989:125-126; 1990:29-32, 31 fig. 17, 96-97; Murray 1991:86; 1995:7-9, 15). ${ }^{19}$

These scenes also contain the admonition not to drink and behave immoderately. Lissarrague (1990:59-65) explains how the paintings on the vases are not simply decorative, but communicate messages to the symposiasts. As a concrete example we can examine, on a painted calyx by the so-called Brygos-painter, the representation of a young man standing upright but with bowed head as he vomits. A young woman (a hetaira, no doubt) holds his head to steady him (cf. Henderson 1997:7; illustration in Arias 1962:photo 138, plate XXXIII). What is the message of this painting? The picture is on the inside of the calyx, where it is covered by the wine. As the symposiast imbibes, the picture is revealed. There is a similar scene on a vase in the Antikenmuseum in Berlin (cf. Durand, Frontisi-Ducroux \& Lissarrague 1989:126, fig. 170). Maas \& Snyder (1989:86, 115, 132 fig. 8) cite two other examples: a bearded man vomiting into a basin while a boy holds his head (Copenhagen 3880); and a man bringing up a stream of wine while leaning on a staff and holding a cup at arm's length, while a boy holds a barbiton (Cleveland 24.197).

19 In extant Greek lyric poetry there is another group of humans accused of bad behaviour: they are the outsiders, the "others", excluded from "our" symposion. I dealt with this subject in a separate article, "Men behaving badly: Conduct and identity at Greek symposia", Akroterion 44 (1999:313). 
A naked man vomitting is portrayed under each handle of an amphora in the White \& Levy collection in New York (Carpenter 1995:155-157). The message is clear: "Do not drink too much or this will happen to you." This moral injunction to avoid excess

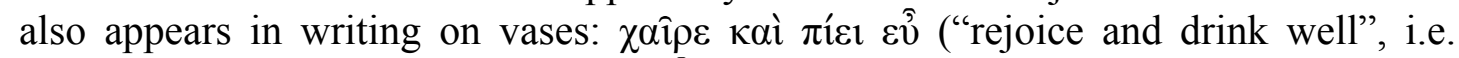

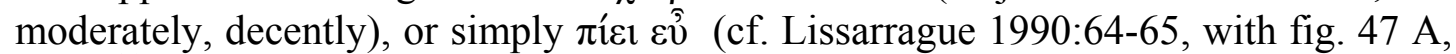
$\mathrm{B}, \mathrm{C})^{20}$

\section{Conclusion}

From the evidence at our disposal it is clear that the symposion in Greek society was the focal point of a complex nexus of activities and behaviour which exerted a widespread and profound influence on the communities of the Greek city-states. We can certainly agree with Murray (1990b:7) that the symposion is central to the understanding of Greek art, literature, religion and history. Especially in the archaic period, it provided the ambience conducive to physical relaxation and intellectual stimulus. Bonds of friendship and political and social alliances were formed, poetry was created and performed, ideas were tested and disseminated, and codes of behaviour formulated into moral ideals within and beyond the dining-room. That is was an exclusively aristocratic institution made it vulnerable to democratic developments. Its nature, function and role in Athenian society were bound to change. Solon already saw signs of the deterioration that would be more pronounced from the next century.

The texts garnered from sympotic melic poetry add their particular contribution to our understanding of the symposion. They not only provide details of the physical milieu of the symposion: they are the voices of the participants that we can still hear-albeit broken, intermittent and partially understood. They speak of their joys and pleasures, hopes and fears, feelings and thoughts. They break the silence of the archaeological remains.

\section{BIBLIOGRAPHY}

Adrados, F R 1975. Festival, Comedy and Tragedy: The Greek Origins of Theatre. Trans. by C. Holme. Leiden: Brill [= Fiesta, Comedia y Tragedia. Sobre los origines griegos del teatro. Barcelona 1972].

Arias, P E 1962. A History of Greek Vase-Painting. London: Thames and Hudson.

20 Drunkenness is also portrayed as a storm at sea and ultimate shipwreck; cf. Lissarrague 1990a:109-10, who refers to Pind. fr. 124 (discussed above). Cf. the discussion by FrontisiDucroux (1989:151-6) on the "eye-cups", which perform a similar prophylactic function, warding off the ill-effects of the wine or the evil eye in general, and imposing control over the proceedings ("somebody's watching you"). Yet at the same time, she argues, as the banqueter drinks from the cup, the eyes become a mask similar to that of Dionysus shown in bacchic scenes; the drinking of the wine (putting on the mask) symbolizes acceptance of the power of the god in a kind of epiphany, with resultant exhuberance, frolics, liberties and liberating madness. Cf. Lissarrague (1990a:140-3), who stresses the power of the eyes to fascinate and create illusion. 
Bérard, C et al. (eds) 1989. A City of Images: Iconography and Society in Ancient Greece. Princeton: Princeton University Press.

Bérard, C \& Bron, Ch 1989. Satyric revels. In Bérard et al. 1989:131-149.

Bergquist, Birgitta 1990. Sympotic space: A functional aspect of Greek dining-rooms. In Murray 1990a:37-65.

Bielohlawek, K 1940. Gastmahls- und Symposionslehren bei griechischen Dichtern. (Von Homer bis zur Theognissammlung und Kritias). WS 58:11-30.

Boardman, J 1990. Symposion furniture. In Murray 1990a:122-131.

Booth, A 1991. The age for reclining and its attendant perils. In Slater 1991a:105120.

Bowie, A M 1997. Thinking with drinking: Wine and the symposion in Aristophanes. JHS 117:1-21.

Bremmer, J N 1990. Adolescents, symposion and pederasty. In Murray 1990a:135148.

Burkert, W 1991. Oriental symposia: Contrasts and parallels. In Slater 1991a:7-24.

Carpenter, T H 1995. A symposion of gods? In Murray \& Tecuşan 1995:145-163.

D'Arms, J H 1990. The Roman convivium and the idea of equality. In Murray 1990a:308-320.

Dickie, M W 1984. Hêsychia and hybris in Pindar. In Gerber, D E (ed.), Greek Poetry and Philosophy: Studies in Honour of Leonard Woodbury, 83-109. Chico: Scholars Press.

Durand, J-L, Frontisi-Ducroux, F \& Lissarrague, F 1989. Wine: human and divine. In Bérard et al. 1989:121-129.

Fisher, N R E 1989. Drink, hybris and the promotion of harmony. In Powell, A (ed.), Classical Sparta: Techniques behind her Success, 26-50. London: Routledge.

Frontisi-Ducroux, F 1989. In the mirror of the mask. In Bérard et al. 1989:151-165.

Hägg, R (ed.) 1983. The Greek Renaissance of the Eighth Century B.C.: Tradition and Innovation. Stockholm: Paul Aströms Förlag.

Harris, W V 1989. Ancient Literacy. Cambridge, Mass./London: Harvard University Press.

Henderson, W J 1973. The paraklausithyron motif in Horace's Odes. AC 16:51-67.

Henderson, W J 1988. Lyric poetry in early Greek education. In Sienaert, E \& Bell, N (eds), Catching Winged Words. Oral Tradition and Education, 1-13. Durban: Natal University Oral Documentation and Research Centre.

Henderson, W J 1992. Pindar Fr. 140b Snell-Maehler: The chariot and the dolphin. Hermes 120:148-158.

Henderson, W J 1997. Elegie en sumposion. Akroterion 42.1:4-22.

Henderson, W J 1999. Men behaving badly: Conduct and identity at the Greek symposia. Akroterion 44:3-13.

Hug, A 1960a. Symposion. In Pauly, A F, Wissowa, G \& Kroll, W (eds) 1960 [1932]. Realencyclopädie der classischen Altertumswissenschaft, IVA.1, 1266-1270. Stuttgart: Alfred Druckenmüller Verlag.

Hug, A 1960b. Symposion-Literatur. In Pauly, Wissowa \& Kroll 1960 [1932]:IVA.2, 1273-1282.

Lamer, H 1965. Komos. In Pauly, A F, Wissowa, G \& Kroll, W (eds) 1965 [1922]. 
Realencyclopädie der classischen Altertumswissenschaft, XI.2, 1286-1304. Stuttgart: Alfred Druckenmüller Verlag.

Latacz, J 1990. Die Funktion des Symposions für die entstehende Griechische Literatur. In Kullmann, W \& Reichel, M (eds), Der Übergang von der Mündlichkeit zur Literatur bei den Griechen, 259-264. ScriptOralia 30. Tübingen: Gunter Narr Verlag.

Lissarrague, F 1990a. The Aesthetics of the Greek Banquet. Images of Wine and Ritual. (Un flot d'images, Paris 1987). Trans. by Szegedy-Maszak, A. Princeton: Princeton University Press.

Lobel, E \& Page, D L 1968 [1955]. Poetarum Lesbiorum Fragmenta. Oxford: Clarendon Press.

Lukinovich, Alessandra 1990. The play of reflections between literary form and the sympotic theme in the Deipnosophistai of Athenaeus. In Murray 1990a:263271.

Maas, Martha \& Snyder, Jane McIntosh 1989. Stringed Instruments of Ancient Greece. New Haven/ London: Yale University Press.

Martin, J 1931. Symposion: Die Geschichte einer literarischen Form. Paderborn: Schöningh.

Mau, A 1958. Comissatio. In Pauly, A F, Wissowa, G \& Kroll, W (eds) 1958 [1900]. Realencyclopädie der classischen Altertumswissenschaft, IV.1, 610-619. Stuttgart: Alfred Druckenmüller Verlag.

Murray, O 1983a. The symposion as social organisation. In Hägg 1983:195-199.

Murray, O 1983b. The Greek symposion in history. In Gabba, E (ed.), Tria Corda. Scritti in onore di Arnaldo Momigliano, 257-272. Como: Edizioni New Press.

Murray, O (ed.) 1990a. Sympotica: A Symposion on the Symposion. Oxford: University Press.

Murray, O 1990b. Sympotic history. In Murray 1990a:3-13.

Murray, O 1990c. The affair of the mysteries: Democracy and the drinking group. In Murray 1990a:149-161.

Murray, O 1991. War and the symposion. In Slater 1991a:83-103.

Murray, O \& Tecuşan, M (eds) 1995. In Vino Veritas. London: British School at Rome.

Murray, O 1995. Histories of pleasure. In Murray \& Tecuşan 1995:3-17.

Page, D L 1975 [1962]. Poetae Melici Graeci. Oxford: Clarendon Press.

Page, D L 1974. Supplementum Lyricis Graecis. Oxford: Clarendon Press.

Pellizer, E 1990. Outlines of a morphology of sympotic entertainment. In Murray 1990a:177-184.

Race, W H 1997. Pindar. Vol. 1: Olympian Odes, Pythian Odes. Vol. 2: Nemean Odes, Isthmian Odes, Fragments. Loeb Classical Library. Cambridge, Mass./ London: Harvard University Press.

Rathje, A 1990. The adoption of the Homeric banquet in Central Italy in the Orientalizing period. In Murray 1990a:279-288.

Reitzenstein, R 1893. Epigramm und Skolion. Ein Beitrag zur Geschichte der alexandrinischen Dichtung. Gießen: J Richter. Reprinted 1970. Hildesheim: Georg Olms. 
Rösler, W 1990. Mnemosyne in the symposion. In Murray 1990a:230-237.

Rösler, W 1995. Wine and truth in the Greek symposion. In Murray \& Tecuşan 1995:106-112.

Schmitt-Pantel, P 1990. Sacrificial meal and symposion: two models of civic institutions in the archaic city? In Murray 1990a:14-33.

Slater, W J 1990. Sympotic ethics in the Odyssey. In Murray 1990a:213-220.

Slater, W J (ed.) 1991a. Dining in a Classical Context. Ann Arbor: University of Michigan Press.

Slater, W J 1991b. Introduction. In Slater 1991a:1-5.

Snell, B \& Maehler, H 1970. Bacchylides. Leipzig: Teubner Verlagsgesellschaft.

Snell, B \& Maehler H 1975. Pindarus. Pars 2: Fragmenta, Indices. Leipzig: Teubner Verlagsgesellschaft.

Tecuşan, M 1990. Logos sympotikos: Patterns of the irrational in philosophical drinking: Plato outside the Symposion. In Murray 1990a:238-260.

Tzavella-Evjen, H 1983. Homeric medicine. In Hägg 1983:185-188.

Van Groningen, B A 1960. Pindar au banquet. Leiden: A W Sythoff.

Vetta, M (ed.) 1983a. Poesia e simposio nella Grecia antica. Bari: Universale Laterza.

Vetta, M 1983b. Poesia simposiale nella Grecia arcaica e classica. In Vetta 1983a:XILX.

Von der Mühll, P 1983. Il simposio greco. In Vetta 1983a:3-28.

- 1957. Xenophon. Das Gastmahl 70-109. Berlin: Rowohlt.

- 1976. Ausgewählte kleine Schriften (ed. B. Wyss) 483-505. Basel: F Reinhardt.

West, M L 1990. The Anacreontea. In Murray 1990a:272-276.

West, M L 1992 [1971]. Iambi et Elegi Graeci ante Alexandrum cantati. Vol. 2. 2nd edition. Oxford: Clarendon Press. 